\title{
Fortalecimiento de la función rectora de las autoridades sanitarias en las reformas del sector de la salud
}

\author{
José María Marín ${ }^{1}$
}

RESUMEN El fortalecimiento de la capacidad rectora de las autoridades sanitarias, ahora y en futuras dé cadas, es asunto de relieve en el contexto de la reforma sectorial. Implica, entre otras cosas, re plantear el lugar que ocupa la salud en el contexto de las principales tendencias sociales y eco nómicas observables en el mundo en los albores del nuevo siglo, constituidas fundamentalmente por la redefinición del modelo de desarrollo, la creciente participación en el quehacer sanitario de entidades ajenas al Estado, la transición hacia una democracia participativa en diversos países, la modificación del concepto de lo "público" y lo "privado" y la globalización de la eco nomía. En este nuevo panorama, se impone la necesidad de que el sector sanitario asuma una función distinta: coordinar la movilización de los recursos nacionales, a escala multisectorial, con miras a mejorar la equidad y el bienestar social y focalizar los escasos recursos que existen en los grupos sociales más desprotegidos.

La liberalización de la producción y de la distribución de los bienes y servicios de salud, así como la dinámica de mercado que se observa cada vez más en el ámbito de estos servicios y la creciente autonomía de los sistemas de aseguramiento, constituyen nuevos retos para el ejerci cio de la autoridad en materia de salud. Adicionalmente, la formación de bloques económicos regionales y el enorme peso ejercido por las grandes compañias multinacionales, con su control del mercado de medicamentos, instrumentos y tecnologías médicas, obligan al sector de la salud a buscar maneras de armonizar la legislación en el ámbito sanitario con las negociacio nes de carácter internacional. Y todas estas exigencias superan, al parecer de no pocos expertos, la capacidad de los ministerios de salud de los países latinoamericanos para responder con la debida eficacia, en vista de las limitaciones impuestas en la actualidad por la organización, poder político, marco jurídico e infraestructura técnica del sector de la salud en los países. Como resultado, estos últimos se ven llamados a dar prioridad al fortalecimiento de la capacidad rectora de sus autoridades sanitarias para hacer frente a los retos del presente y el futuro.

En este artículo se examina el estado actual, con proyecciones al futuro, del fortalecimiento de la capacidad de las autoridades sanitarias para ejercer la rectoría de la salud. Tres premisas básicas sirven de punto de partida para la

\footnotetext{
1 Programa de Organización y Gestión de Sistemas y Servicios de Salud, División de Desarrollo de Sistemas y Servicios de Salud, Organización Panamericana de la Salud. Dirección postal: 525 Twenty-third Street, N.W., Washington, D.C. 20037, Estados Unidos de América. Correo electrónico: marinjos@paho.org
}

reflexión: 1) El papel rector de la autoridad sanitaria no ha surgido como resultado de los procesos de reforma sectorial, pero en dichos procesos adquiere renovada importancia y nuevas formas y contenidos (a la vez que se adecua la capacidad de las entidades que lo ejercen), a raíz de las transformaciones que se han dado en las funciones gubernamentales dentro de los procesos de modernización del Estado. 2) La rectoría de la salud - como política de Estado y como valor y práctica social — abarca la acción del sector pero sin restringirse a ella, y se aplica no solo a los componentes y procesos de la reforma sectorial. 3) Por último, el fortalecimiento de la autoridad sanitaria implica el desarrollo de las capacidades institucionales de quienes deben ejercer la rectoría sectorial en sus diferentes niveles de actuación, y no solo las de las instancias centrales de los ministerios o secretarías de salud. 


\section{¿POR QUÉ REDEFINIR LA FUNCIÓN RECTORA DE LAS AUTORIDADES DE SALUD EN EL ÁMBITO DE LAS REFORMAS DEL SECTOR?}

En los países americanos continúan evolucionando los procesos de modernización de los Estados y, como parte de ellos, los de la reforma del sector de la salud. Es tendencia constante y común de dichos procesos hacer hincapié en la participación social, la descentralización, la separación de funciones en la gestión pública estatal y la aparición de nuevas modalidades y nuevos actores en el financiamiento, aseguramiento y provisión de la atención de salud. Paralelamente, se ha redefinido el modelo de desarrollo y revalorado el papel de lo social y la salud como componentes imprescindibles de los procesos de desarrollo. Igualmente, la transición hacia una democracia participativa y una redefinición del "Estado benefactor" ha llevado a una nueva manera de concebir lo público y las distintas formas de gestión pública. En el marco de estas tendencias, se hizo necesario redefinir el papel y las funciones del Estado en el campo de la salud y, específicamente, el quehacer de la autoridad sanitaria. Como se detalla a continuación, todas estas tendencias están incidiendo en el replanteamiento y la revaloración de la función de rectoría que corresponde a la autoridad sanitaria nacional (1).

En primer lugar, la modernización del Estado impuesta en todos los países de América Latina por las tendencias que muestran mundialmente el desarrollo, la democracia participativa y la liberalización de la economía, ha exigido una modificación de sus estructuras tradicionales y una revisión de su participación en la economía y de sus relaciones con la sociedad civil. En los primeros intentos, el debilitamiento del Estado y sus instituciones se concretó, en general, en la privatización de las empresas y en la prestación de servicios principalmente en los sectores productivos, muchas veces con el propósito inmediato de conseguir recursos fiscales adicionales. Sin embargo, tras esa fase inicial, en la cual el Estado se redujo mediante la transferencia de funciones económicas y sociales del gobierno al mercado, se ha colocado mayor énfasis en la redefinición de las funciones esenciales del Estado, resaltando su papel como garante de los derechos ciudadanos y factor de cohesión social (2).

Frente al fundamentalismo del mercado surgió la reacción de las sociedades. Al superarse la polarización - de alto contenido ideológico- entre el Estado que recauda y reparte y el que confiere libertad de acción, surgió una aproximación pragmática a un modelo de Estado que garantiza el equilibrio entre las fuerzas del mercado y la protección estatal. Ello sucedió en Europa y tuvo proyección internacional con la llamada "Tercera Vía", que buscaba la consolidación de un nuevo equilibrio entre los derechos y deberes ciudadanos en la esfera del sistema de protección social (3). ${ }^{2}$ No se trataba de un movimiento pendular, de regreso a situaciones anteriores, sino del establecimiento de los equilibrios necesarios mediante una nueva visión del Estado, sus funciones y responsabilidades, y su relación con la sociedad civil y el mercado. De ello parten la revisión y el fortalecimiento del ejercicio de la autoridad sanitaria.

En las actuales propuestas de reforma del Estado destacan el fortalecimiento del poder regulador y de producción de políticas públicas por el gobierno, así como la "desgubernamentalización" de la producción de los bienes y servicios públicos. En otras palabras, se ha planteado un nuevo perfil del gobierno como resultado de su concentración en las funciones promotoras de la cohesión social, facilitadoras de la participación ciudadana y reguladoras de la producción y distribución pluralistas y descentralizadas de los bienes y servicios de interés público. No obstante, la reorientación del

\footnotetext{
2 Bill Clinton, presidente de los Estados Unidos de América, planteó este enfoque en su "Discurso sobre el estado de la nación" de 1997.
}

Estado hacia las "funciones propias e indeclinables", incluida entre ellas la protección social, que abarca la salud, es aún imperfecta, y ello coloca las funciones rectoras de la autoridad sanitaria en el centro del debate y de las inquietudes de los gestores de políticas públicas.

En segundo lugar, una condición fundamental del nuevo modelo de desarrollo es la preparación del capital humano y social, siendo la salud uno de sus componentes esenciales y de sus consecuencias deseables. Se trata de un desarrollo humano que vincule el crecimiento económico indispensable en condiciones de estabilidad con un desarrollo social adecuado, y con condiciones de sostenimiento sociales y ambientales; este desarrollo es el objetivo del Estado moderno. En el momento actual se plantea una revalorización de lo social y, simultáneamente, un reconocimiento del papel irrenunciable del Estado en materia de garantía y protección de los derechos ciudadanos, particularmente en las áreas de la salud y la educación (4-7).

El florecimiento de la capacidad creadora de los individuos y de las empresas, así como la contribución de estos al progreso social, son esenciales para el fortalecimiento del Estado de derecho y la expansión y profundización de la democracia, siendo a la vez imprescindible para ello la protección social, especialmente en lo que se refiere a la garantía de niveles de justicia social y equidad.De ahí que en la actualidad se haya planteado la necesidad de concentrar la acción del Estado en funciones estratégicas para el desarrollo del capital humano y social $(8,9)$.

El Estado desempeña un papel central como "sujeto" y a la vez "actor" del desarrollo; tiene la responsabilidad directa de garantizar que se cumplan todas las condiciones necesarias para el desarrollo y que sus resultados se distribuyan equitativamente. Entre las responsabilidades principales del Estado en materia de desarrollo figuran las de movilizar, articular, orientar y apoyar aquellas acciones públicas no estatales, es decir, de la sociedad civil organizada, que estén encaminadas a 
mejorar la salud, las que conforman el quehacer de la autoridad sanitaria.

En tercer lugar, el replanteamiento de la salud, como proceso y producto social y como componente sustantivo del desarrollo humano (10), ${ }^{3}$ obliga a superar los marcos limitados de las tradicionales políticas, planes y acciones del sector de la salud, para dar cabida a factores relacionados con las condiciones de vida y el bienestar social. En tal sentido, la salud concebida y valorada como componente del desarrollo (construido socialmente), y no como actividad remediadora (ejercida por el sector ante el fenómeno de la enfermedad), está fundamentada en el consenso social acerca de la igualdad de los ciudadanos a la hora de satisfacer sus necesidades y expectativas de salud, lo cual determina la responsabilidad de la sociedad y del individuo de definir, promover y conservar la salud como bien colectivo. Y ello a su vez implica revisar la acción en salud y replantearla como un campo de intervención intersectorial en el que diversos actores sociales, y no solo el gobierno y los proveedores de los servicios de salud, se preocupan, deciden e intervienen sobre los factores determinantes y condicionantes del estado de salud de la población.

Como el quehacer de las autoridades sanitarias surge del concepto mismo de la salud, una visión de la salud cada vez más integral y amplia hace que la función rectora trascienda la organización y la acción sectoriales. Aunque las prácticas institucionalizadas de rectoría aún no reflejan adecuadamente ese concepto, las condiciones están presentes para ajustar dichas prácticas a los nuevos conceptos y a las nuevas realidades.

En cuarto lugar, la evolución de la noción de lo público referida a "lo que es de todos y por ende interesa a todos" alude también a las instancias y actores que adoptan las decisiones de interés común y protegen y producen los bienes públicos. El aspecto clave que plantea este enfoque es que la acción colec-

\footnotetext{
3 Organización Panamericana de la Salud. La salud en el desarrollo. Washington, D.C.: OPS; 1991. (Documento del Consejo Directivo).
}

tiva no solamente implica la afirmación y garantía estatal de los derechos ciudadanos, sino también la definición y producción de bienes públicos por la propia sociedad. Bajo la perspectiva anotada, adquieren pertinencia otros valores y prácticas que bien pueden ser calificados de públicos (lo público social) pero que no son los tradicionales estatales (lo público estatal) (11). Igualmente, se reafirma el papel de la sociedad en la toma de decisiones y en la producción de bienes públicos y se reivindican los valores, derechos y responsabilidades de los ciudadanos como sujetos que definen la opinión y voluntad públicas en la gestión pública.

El crecimiento de lo público no estatal estimula y acelera la participación e interacción de nuevos actores sociales y crea una multiplicidad de mecanismos e iniciativas para la participación directa de la sociedad y de las comunidades en la gestión de las políticas públicas. El aumento de dicha participación es a su vez condición y resultado de una democracia efectiva y refuerza la legitimidad del papel representativo de las instituciones políticas en el ejercicio de la autoridad.

El desarrollo de las sociedades y el fortalecimiento de la democracia, como marco de referencia de la participación ciudadana, son los principales factores políticos que condicionan las nuevas prácticas de rectoría de la salud. Se trata de un proceso de intervenciones políticas socialmente legitimadas por su capacidad para responder a las necesidades de salud de las poblaciones, una vez que se logra alcanzar un equilibrio entre distintas opciones, que a menudo encierran conflictos de intereses en condiciones de disponibilidad de recursos colectivos limitada. En dicho marco, las funciones propias de la rectoría de la salud constituyen parte nuclear de la definición del nuevo papel del Estado, al reconocerle su participación legítima como modulador de los procesos y movimientos sociales atinentes a la salud y al bienestar colectivo, en el ejercicio de la autoridad sanitaria.

En todos los casos, los procesos de transición en los que se encuentran los sistemas de salud están bajo la fuerte influencia de la evolución de los enfoques y visiones que se tienen sobre los papeles del Estado y de la sociedad civil, sobre la dinámica entre la salud y el desarrollo y sobre la relación entre lo público y lo privado. En este contexto se reafirma la indelegable responsabilidad que les corresponde a los ministerios o secretarías de salud, como autoridades sanitarias nacionales, en el ejercicio de la rectoría.

\section{ASPECTOS CRÍTICOS DEL FORTALECIMIENTO DE LA FUNCIÓN RECTORA DE LAS AUTORIDADES DE SALUD EN LAS REFORMAS DEL SECTOR}

La transformación del ejercicio y de la capacidad de rectoría, necesaria y justificada por las razones expuestas, motivó que el XL Consejo Directivo de la OPS dedicara una sesión especial a deliberar sobre varios asuntos directamente relacionados con la autoridad sanitaria: la nueva dimensión de la función rectora de los ministerios de salud dentro del sector sanitario; el liderazgo de este último en la defensa de la salud como componente del desarrollo humano; la redefinición de las funciones fundamentales para el ejercicio de la rectoría sectorial; los requisitos para desarrollar la capacidad institucional de los ministerios de salud de ejercer dicha rectoría; y las orientaciones de la cooperación de la OPS para fortalecerla. ${ }^{4}$

Quedaron definidos el objetivo y los contenidos de las funciones en cuanto a: 1) conducción, 2) regulación, 3) acciones de salud pública propias de la autoridad sanitaria, 4) modulación de la financiación, 5) garantía del aseguramiento y 6) armonización de la provisión de servicios que integran el nuevo perfil de la rectoría dentro del sector. Pero aún falta profundizar en

\footnotetext{
4 Organización Panamericana de la Salud. La rectoría de los ministerios de salud en los procesos de reforma sectorial. Washington, D.C.: OPS; 1997. (Documento CD40/13).
} 
algunas cuestiones relacionadas con los aspectos operacionales del ejercicio de tales funciones, como sus ámbitos de acción; las formas y medios de ejercerlas, según las características y condiciones de la autoridad sanitaria en el Estado moderno y en un sector que ha sido reformado. Estos aspectos operacionales son los menos desarrollados hasta ahora en los procesos de reforma del sector. Examinemos algunos aspectos críticos de cada una de las funciones mencionadas.

La función de conducción sectorial busca lograr una actuación directiva más eficaz en las decisiones relacionadas con la orientación y movilización de los recursos nacionales hacia un desarrollo de la salud que contribuya a niveles mayores de equidad y bienestar social, tanto para la generación actual como para las futuras. El nuevo concepto de la salud en el desarrollo exige replantear el objeto y las formas de conducción sectorial, confiriéndole al proceso el carácter de intervención intersectorial, con múltiples actores sociales, frente a los procesos biológicos, ecológicos, culturales y socioeconómicos que predominan en una sociedad y en un momento dados.

El Estado, como garante del ejercicio pleno y efectivo de los derechos ciudadanos, debe poner especial énfasis en facilitar la concertación de los sectores público, privado, social solidario (ONG) y la comunidad, para que todos los recursos disponibles en la sociedad para los programas sanitarios concurran a la cobertura universal con equidad. Se trata de formar una red social de protección y servicios donde el sector público de la salud asigne prioridad a los problemas y grupos sociales más desprotegidos, conforme el principio de la equidad, y focalice los escasos recursos públicos en la atención de los grupos más vulnerables y con menos capacidad de acceso, con un propósito francamente redistributivo. Nada de esto está exento de conflictos de intereses y de una lucha por el poder en una sociedad pluralista y democrática y ello naturalmente afecta al ámbito, al estilo y a los medios de la conducción sectorial.

Los Gobiernos nacionales están llamados a encontrar nuevas formas para

\section{Essential functions of Canada's public health care system, decentralization, and tools for quality assurance: consistency through change in the Canadian health system}

\author{
Ed Aiston, ${ }^{1}$ Kate Dickson, ${ }^{1}$ and Nick Previsich ${ }^{1}$
}

\begin{abstract}
"Canadians care deeply about their health and the health system. As a nation we want to continue to live healthy and productive lives. We now know that increasing our understanding of how such factors as income, education, housing, and support from family and friends influence our health will allow us to make further gains in improving health and reducing inequities."

-Michael Decter, Chair of the Canadian Institute for Health Information

3 February 2000
\end{abstract}

The high standard of living and health care enjoyed in Canada can be attributed to the strong partnerships that have evolved between the federal government and the provincial and territorial governments since the 1950s and 1960s, when the current health care system was being established. The Government of Canada's role in health care involves passing legislation and setting and administering national principles, standards, and regulations. The Government also helps finance provincial and territorial health care services through fiscal transfers. Using such policy instruments as direct spending, taxation measures, regulation, and information services, the Government of Canada has actively supported the provinces in developing health status objectives, producing comparative health status reports, conducting research on medical practice organizations, performing economic analyses of medical intervention alternatives, and assessing new technologies. Additional federal health responsibilities include developing strategies for health promotion and illness prevention and education and providing accurate and timely health information upon which Canadians can base their individual choices and decisions.

\footnotetext{
${ }^{1}$ Health Canada, International Affairs Directorate, Ottawa, Ontario, Canada. Send correspondence to: Nick Previsich, International Directorate, Health Canada, email: nick_previsich@isdtcp3.hwc.ca
} 
The direct management of health services is the responsibility of each province or territory. Through their respective health ministries, the provinces and territories plan, finance, and evaluate the provision of hospital care, physician and allied health care services, and some elements of prescription care and public health. The provinces and territories also supervise the specific responsibilities that are delegated to other, nongovernmental agencies. Provincial health ministries fund public hospitals, negotiate salaries of allied health professionals, and negotiate fees for physician services with provincial physician associations. In all cases, a schedule of benefits for physician services under the Health Insurance Act is published and available to the public.

\section{National Forum on Health}

In 1994 the Government of Canada launched the National Forum on Health with a mandate to "involve and inform Canadians and to advise the federal government on innovative ways to improve our health system and the health of Canada's people." Published in 1997, a resulting five-volume report entitled Canada Health Action: Building on the Legacy found that the Canadian health care system was fundamentally sound and recommended that its core characteristics remain unchanged. Sustaining Canada's health system will require a balance of actions on nonmedical determinants and of actions by the health system itself. On economic grounds, the Forum concluded that the single-payer model of public health insurance is the best approach to controlling overall spending on health. This Medicare system ensures that Canadians receive medical attention when they need it and avoids the duplication and inefficiency of a system with hundreds of private plans.

The Forum endorsed the concept of continuous quality improvement, defined as "a strategic, integrated management system for achieving customer satisfaction." The Forum supported quality assurance in health care, described as "the measurable and sustained achievement of preferred outcomes through appropriate collaboration and based on need." The Forum recognized there were unexplained variations across the country in rates of surgical procedures, number of hospital days being used by those who did not require acute care, and levels of inappropriate use of drugs. The Forum recommended that: 1) resources be used more efficiently within the system (as opposed to being increased), 2) collaboration be strengthened among organizations, providers, and consumers, 3) existing services be realigned, and 4) decision-making be evidence based. The Forum also recommended that steps be taken to bring home care and medically necessary drugs (referred to as Pharmacare) under the umbrella of the publicly funded health care system. In other words, out-of-hospital services should be made an integrated part of publicly funded health services and should reflect an approach to "funding the care, rather than the provider or site," by being based on need instead of supply. que la sociedad civil participe de manera efectiva y con más influencia en las decisiones que afectan a su futuro, como lo es el desarrollo de la salud. Por tal motivo, el ejercicio de la conducción sectorial está condicionado por el propósito de construcción de la ciudadanía y la consolidación de la democracia participativa.

La acción directiva en el ámbito de la salud es un proceso social esencialmente político que significa, en efecto, asignar valores esenciales a la sociedad directamente relacionados con el principal derecho humano: la protección de la vida. Hay en las sociedades múltiples visualizaciones de la salud deseada y de cómo se deben producir las situaciones que las hacen posibles. Esas múltiples visiones, muchas veces en conflicto, están sustentadas por actores sociales que poseen distinta capacidad para influir en el proceso político: en las decisiones (o ausencia de ellas) y en la posibilidad de ejecutarlas. Es necesario, por lo tanto, construir políticamente los objetivos sociales en el ámbito de la salud (viabilidad con base ética) y especificar técnicamente las condiciones concretas que permiten alcanzar esos objetivos finales (factibilidad técnico-administrativa) (12).

Conducir la política pública de salud, es decir, dirigir los procesos estatales y sociales relacionados con la valoración y práctica de la salud, también implica la participación y responsabilidad de múltiples actores sociales (además de las instituciones que tradicionalmente constituyen el sector formal de la salud) no solo en la ejecución de programas y la provisión de servicios, sino principalmente en la concertación de objetivos y estrategias de intervención para afrontar problemas prioritarios y en la movilización de los recursos necesarios. De ahí que constituya un proceso de liderazgo político y técnico para la cohesión social y la participación ciudadana en la definición y ejecución de políticas públicas que concitan múltiples intereses y disponen de escasos recursos.

La acción política de conducir la salud se hace desde el gobierno, en el Estado mismo, y desde ahí hacia la sociedad. En la orientación general de 
todo el sector, es indispensable la actuación del Estado, que tiene el derecho de decidir por toda la sociedad y de usar su poder legal de coacción (fuerza) para que las decisiones sean acatadas. El reto en el proceso de conducción de la salud radica en balancear la acción de la sociedad (poder real) con la acción del Estado (poder formal), haciéndolas converger hacia objetivos y estrategias comunes de desarrollo. Así se explica que la conducción de la política nacional de salud obligue al órgano rector no solo a ofrecer dirección adecuada a cada uno de los organismos que integran el sector de la salud y a coordinar el funcionamiento de dichos organismos, a efectos de que cumplan los fines institucionales del sistema de salud, sino también a promover y coordinar las intervenciones de otros sectores del desarrollo nacional que influyen en el área bajo la responsabilidad del sector sanitario.

En una sociedad democrática con un concepto amplio de la salud e integrada por distintos sectores y por actores públicos y privados, las preguntas clave a las que cada país deberá responder versan sobre los contextos, contenidos, requisitos, formas y medios para el ejercicio de la responsabilidad gubernamental de dirigir la política pública de salud en la nueva sociedad, desde el Estado moderno y con un sector reformado. Se plantean interrogantes tales como ¿cuál es el objeto de la conducción? ¿a quién se conduce? y ¿cómo se conduce? En la búsqueda de las respuestas, las cuestiones básicas de la gobernabilidad y del ejercicio democrático del poder deben ser examinadas con profundidad y ánimo realista.

En términos propositivos, el carácter politicotécnico del proceso de conducción confiere no solo viabilidad, sino también gobernabilidad, uniendo viabilidad con factibilidad (poder de gobierno y apoyo de la sociedad, más capacidad operativa institucional) en el ejercicio democrático de la rectoría. Eso es posible siempre que se articulen las acciones gubernamentales de formulación política con las acciones de apoyo de la sociedad civil (poder for-

The Forum also recommended that primary care services be carefully restructured. It did not put forward any particular model, but suggested that any reform of primary care include: 1) a realignment of funding to the patients, not services and 2) a remuneration method not based on volume of services provided by physicians but that promotes a continuum of preventive and treatment services and the use of multidisciplinary teams.

The Forum concluded that concerted actions based on informed decisions were needed to make the health care system more efficient, effective, and reflective of contemporary practice in health care delivery. A key objective should therefore be to rapidly develop an evidence-based health system, in which decisions are made by health care providers, administrators, policymakers, patients, and the public on the basis of appropriate, balanced, high-quality evidence. Federal leadership in developing a nationwide population health information system was considered essential. Such a system would bring together a standardized set of longitudinal data on health status, health determinants, and health system performance, and would ensure patient privacy and confidentiality.

\section{Current directions for health in Canada - decentralization for improved population health}

In its 1997 budget the Government of Canada acted on a number of the National Forum recommendations. A Health Transition Fund of Can\$ 150 million over three years was established to allocate funds to the provinces for pilot projects leading to better approaches to health care delivery, including home care, coverage for medically necessary drugs purchased outside the hospital, and primary care reform. An additional Can $\$ 50$ million over a three-year period was put in place to launch a Canada Health Information System. Also being implemented are several programs to improve the health and wellbeing of children. An Aboriginal Health Institute has been established, and in November 1999 legislation was introduced to create the Canadian Institute(s) of Health Research. That Institute would organize, coordinate, and fund health research at the federal level and further evidence-based decision-making for quality assurance and efficiency in the use of resources.

Since 1991 most of the provincial governments have undertaken structural reforms involving the transfer of authority for both the health of populations and the provision of health services from the province to the subordinate regional or district level. In some cases these regional health authorities have also become responsible for the social programs. All the provinces have expressed a commitment to shifting the emphasis of their health systems away from institutionally based delivery models to community-based models that place increased emphasis on health promotion, disease prevention, a client focus, and strategic quality planning. Institutional restructuring has 
involved the consolidation of certain specialty services at designated hospitals, the closure of some hospitals, and the redesignation of some hospitals as community health centers. In addition, almost every province is moving toward improved service integration for the full continuum of care. Methodologies in the provinces have included integrating programs at the provincial level (Prince Edward Island and Newfoundland); using regional health authorities as the integrating body (Saskatchewan); targeting services to a specific population segment (senior citizens in Alberta; youth in Manitoba); integrating services for a particular disease category (cancer care in Ontario); and community-level initiatives (cities of Toronto and East York). All the provinces have also taken steps to develop "wellness" strategies, have begun to place more emphasis on developing primary care models and networks, and have increased funding for home care. Better information systems and closer linkages with teaching and research are also being developed as part of a new public sector results orientation that seeks to enhance integrity, transparency, and effective performance.

Information about how determinants, risk factors, and interventions relate to health outcomes is essential to protecting the health of Canadians. One response has been the Health Services Utilization and Research Commission (HSURC) in Saskatchewan. It is an arm'slength, government-funded agency that assesses the province's health system and makes recommendations for evidence-based change. HSURC is also the provincial health research granting agency. Other responses have included the Canadian Coordinating Office for Health Technology Assessment and the British Columbia Office of Health Technology Assessment. They were both established to influence decision-making on the appropriate use of health technology, by collecting, analyzing, creating, and disseminating information on the effectiveness, cost, and health impact of technology. The technologies of concern include all procedures, devices, equipment, and drugs used to maintain, restore, and promote health care.

The formation of the regional health authorities in the provinces has in turn required the development of new and flexible funding arrangements that allow the health services to fit the devolution to the regions of responsibility for hospital services, long-term care, and diagnostic and community services. Funding is allocated on the basis of the districts' population and health care needs, and it is adjusted according to the age and gender of the population served and the patterns of health service delivery. For institutional acute care services, the basic need indicators used are the standardized mortality rate, low birthweight rates, and a fertility factor. Institutional supportive care services recognize districts with higher proportions of elderly living with family or nonrelatives as having more need for services, and home-based services take into account districts with more elderly living alone or with family members. There is, however, widespread concern about the potential cost of insured home care and pharmaceutical programs, and opinions also diverge mal y poder real, respectivamente) en un ejercicio democrático del poder de gobierno, y que se preparen simultáneamente las condiciones técnicoadministrativas de factibilidad.

Entre las funciones que adquieren mayor relevancia en el nuevo perfil de la rectoría sectorial se encuentran la regulación y su necesario correlato de vigilancia. La regulación (requisitos mínimos y normas de calidad, sobre todo) y la vigilancia de su aplicación expresan el "poder policiaco", la autoridad coercitiva legal de la rectoría. Con ella se complementan la persuasión, el convencimiento y el consenso en la promoción de comportamientos deseados, que son mecanismos de conducción. Esta función se hace cada vez más necesaria para garantizar el papel estatal de ordenar las relaciones de producción y distribución de los recursos, bienes y servicios de salud en función de principios de solidaridad y equidad; pero a la vez se circunscribe cada vez más a los aspectos esenciales debido a la expansión de las economías de mercado y la tendencia a la desregulación.

La liberalización de la producción y distribución de los bienes y servicios de salud; la dinámica de mercado en la atención de salud; y la mayor autonomía y suficiencia en el aseguramiento y el financiamiento, plantean nuevos retos que son vitales para el ejercicio gubernamental de regular y vigilar el cumplimiento de la política pública de salud. Por ello, a la hora de ejercer la función reguladora, la autonomía e interdependencia de los bienes privados y públicos y sus implicaciones para la solidaridad y la equidad no pueden ser obviadas.

Los procesos de globalización y de integración regional también afectan a la acción reguladora estatal en el campo de la salud, pues la producción, comercialización y utilización de muchos recursos (en cuanto a ejercicio profesional, estándares de calidad, precios de materia prima y medicamentos, transferencia de tecnologías, etc.) son ahora objeto de acuerdos internacionales. La globalización ha dado origen a que los instrumentos de política interna de los países sean objeto de negociacio- 
nes internacionales. Las políticas sociales, y no solo las ambientales y económicas, ya no son de exclusiva competencia interna, sino que además tienen grandes implicaciones internacionales que exigen un marco de referencia adecuado para integrar el proceso de decisiones nacionales dentro del contexto de la salud internacional. La asimetría en la participación y capacidad de decisión de los países, las subregiones y el sector de la salud en temas que afectan a las políticas y rectoría de la salud a nivel nacional obliga a pensar en mecanismos compensadores del rezago del sector y de los países con menos protagonismo en los nuevos esquemas integradores.

La internacionalización de la economía, la conformación de bloques regionales y el peso relativo de las empresas multinacionales en el manejo de los insumos médicos, la tecnología y los medicamentos, hacen que la armonización de la legislación y reglamentación de la salud se esté constituyendo para las autoridades sanitarias en una prioridad reguladora de primer orden que exige no solamente el conocimiento del sector de la salud sino una capacidad especial en materia de negociación internacional.

En un contexto cada vez menos regulado por los Gobiernos nacionales y más sujeto a la ley del mercado y a los acuerdos regionales, donde el financiamiento, la provisión y el aseguramiento son resultados de una relación contractual o voluntaria de individuos y grupos con empresas de carácter privado o solidarista, es necesario responder a preguntas como: ¿En qué campos es imprescindible regular, y en qué medida y cómo? En la búsqueda de las respuestas, el asunto de la liberalización de la producción y distribución de un bien público y sus consecuencias sociales y económicas tiene que ser debatido.

En lo que respecta al objeto y la profundidad de la función de regulación, es necesario definir el universo conformado por las distintas modalidades normativas aplicables en el sector y en otras áreas del desarrollo nacional, abarcando desde los temas propios de la actividad asistencial o de la prestación de los servicios hasta los relacionados con la protección del ambiente o

on home care and Pharmacare. In response to the need to measure the impact of these changes across the country, new accountability mechanisms are emerging. The provinces of Alberta, British Columbia, New Brunswick, Newfoundland, Nova Scotia, and Saskatchewan have all published formal accountability framework documents incorporating macrolevel public accountability, the opportunity for public interaction and influence, and health system performance reporting.

The search for quality assurance has led many of the provinces in Canada to develop their own health needs assessments as a basis for policy development and program implementation. These comprehensive assessments involve systematically collecting and analyzing information about underlying causes of health, illnesses, and injuries, including income, social status, education, employment opportunities, and the availability of preventive and primary care health services. The assessments encompass a geographical area or a particular group of people. The information is usually shared with planners, staff, other partners, and community members in order to develop policies and programs to improve and maintain health.

To strengthen policy development and program planning in Canada, national consensus indicators have been developed, as have specific provincial indicators in Newfoundland, Nova Scotia, Prince Edward Island, and Saskatchewan. These indicators include ones for the social and economic environment, the physical environment, health care, lifestyles and coping skills, human biology, child development, health status, and health system performance.

In the province of Prince Edward Island, "decision support tools" have been developed to improve understanding among health care providers and regional authorities of the conceptual framework of cross-sectoral reallocation (CSRA). CSRA refers to shifts in resources from one sector to another to improve the health of entire populations or target groups. Some examples are shifts from institutional health care services to community-based health care programs, or from health care services to such social services as income or employment supports. These tools create a favorable climate for CSRA, reduce conflict, assist in decision-making, and maintain support from health care providers, the media, and the public at large.

\section{Current challenges for health in Canada}

Canada's health care system is recognized as one of the best in the world, with its principles of universality, comprehensiveness, reasonable access, portability, and public administration. The system, however, does face challenges. A leading issue in the health sector reform process has been sustaining solidarity on the use of public taxes to fund health care in exchange for maintaining a readily accessible, high-quality system. 
Canada has one of the highest levels of self-rated health among citizens of developed countries, with $63 \%$ of adult Canadians saying their health is excellent or very good, and only $9 \%$ rating their health as fair or poor. Despite that fact, there is growing public concern that a decade of funding and staff cutbacks has eroded the health care system. This has led to a number of initiatives designed to maintain quality and determine effectiveness.

Through its 1999 budget, the Government of Canada allocated federal transfers of Can\$ 11.5 billion over five years for the provinces and territories to address their health care priorities. According to projections of the Canadian Institute for Health Information (CIHI), spending on Canada's health care system was expected to rise by $5 \%$ in 1998 and a further $5.1 \%$ in 1999 . Hospital care remains the leading category of health expenditures, although its share of the total has steadily declined since the mid-1970s. Sales of prescription and nonprescription drugs are replacing spending on physician services as the second largest category. These rising costs are attributed to the growth of high-cost technologies, combined with a rapidly aging, more informed, and assertive population that is placing increased demands on the health care system.

There is also concern about the availability of trained nurses and physicians and the sustainability of the system. The reduction in medical school size in the early 1990s has meant that young physicians are not there to replace those who wish to retire. Despite this concern, Canada's physician supply grew $1.7 \%$ in 1997-1998, largely due to increases in the number of specialists and the number of physicians returning from abroad to work in Canada.

Continuing reforms of the health care and health financing system are essential, including with primary health care and home care. Also needed are refined community health models involving partnerships among doctors, nurse practitioners, nurses, and other health care providers, so as to make the most efficient use of resources. A HSURC report on Saskatchewan released in September 1999 looked at hospital use patterns and found that funding cuts did not adversely affect rural residents' health status or their access to health services. In February 2000 Canada's Health Minister and the chair of the Canadian Institute for Health Information announced the appointment of a governing council of the Canadian Population Health Initiative. The council will promote state-of-the-art analysis of research findings and make the resulting information accessible in innovative ways. The Western Canada Waitlist Project, to be released in the summer of 2000, will help Canadians better understand and manage waiting lists for health care services. These efforts and others will assist Canadians in making decisions that will improve their health and that of their families and communities. las normas sobre insumos o productos que inciden en los problemas de salud. Este reto exige la construcción de un conjunto básico de regulaciones para el sector que sean instrumento de apoyo y no de desaliento, de armonización y no de confusión, de eficiencia y racionalidad y no de duplicaciones y desperdicios en la utilización de los recursos. También exige que dichas regulaciones determinen las condiciones mínimas, los medios y los procedimientos apropiados para alcanzar los objetivos sociales en el ámbito de la salud, previo el desmonte de regulaciones centralistas y de intensa limitación del mercado libre (13).

En el campo de la vigilancia se ha venido acumulando una experiencia con la operación de las superintendencias y es necesario reflexionar sobre cómo encajan en la estructura y en la responsabilidad estatales para el ejercicio de la autoridad sanitaria. Las hipótesis básicas para dicha reflexión son que la autoridad sanitaria es ejercida por los ministerios o secretarías de salud y que contempla entre sus funciones la vigilancia; y que para el ejercicio de las funciones orientadas al control del cumplimiento de lo regulado, dichos entes rectores se apoyan en las superintendencias. Interesa conocer, por tanto, hasta qué punto estas se conciben, se organizan, funcionan y se relacionan como instrumentos especializados para el ejercicio de ciertas actividades de vigilancia y control que son competencia natural de la autoridad sanitaria.

El desarrollo de las funciones esenciales de salud pública propias de la autoridad sanitaria compete a los ministerios o secretarías de salud en sus diferentes niveles de dirección, como órganos del Estado responsables de velar por el bien público en materia de salud. En la actualidad se plantea una revisión de las funciones sustantivas de salud pública y de las tareas indelegables de la autoridad sanitaria, en el marco de un concepto replanteado de la salud y de un proceso descentralizador (14). ${ }^{5}$

5 Guerra de Macedo C. La salud pública en las Américas: documento conceptual y operativo [borrador]. Washington, D.C.: OPS; 1999. 
En este contexto, es preciso definir cuidadosamente el ámbito de la salud pública y de los mecanismos vinculantes para ejercer con efectividad la autoridad sanitaria en materia de promoción y protección de la salud poblacional como bien público, debido a sus consecuencias políticas, sociales y económicas. Es necesario dar respuesta a preguntas como cuáles son las áreas sustantivas y los medios de intervención de la autoridad sanitaria en materia de salud pública, sobre todo, cuando esta trasciende las fronteras sectoriales y nacionales y es responsabilidad y práctica que comparten las autoridades del gobierno, la sociedad y los individuos. En la búsqueda de las respuestas, tienen que definirse el ámbito de competencia de los entes rectores en materia de salud pública y los mecanismos vinculantes para ejercer la autoridad con efectividad. En dicho ámbito destaca la función de inteligencia para un análisis sistemático, continuo y ágil orientado a identificar e interpretar las ventajas, debilidades, oportunidades y amenazas planteadas por los aspectos políticos, sociales, económicos, epidemiológicos, tecnológicos y administrativos que afectan al desarrollo de la salud y, a partir de ello, abogar por las condiciones y comportamientos que favorezcan la salud y la vida.

El pluralismo en las fuentes y los cambios en las formas de financiación de la atención de la salud - conceder un mayor peso relativo a los recursos privados, focalizar los recursos públicos en los grupos postergados y subsidiar la demanda- están generando nuevos esquemas de responsabilidad estatal e individual en los cuales las prácticas de contratación y competencia plantean desafíos importantes para la capacidad rectora del sector. Ante ello, los ministerios o secretarías de salud tienen una capacidad limitada de decisión sobre las asignaciones financieras, especialmente sobre las de las otras instituciones del sector, y no tienen mecanismos sistematizados para modular el financiamiento y el gasto en salud. Mientras más se intensifique la ten- dencia hacia la financiación directa por parte del individuo o mediante los sistemas de aseguramiento, mayor será la necesidad de sentar criterios y crear mecanismos para el análisis y control por parte del Estado del financiamiento y el gasto en salud. Para el desarrollo de esta capacidad rectora, es necesario responder a preguntas como ¿en qué medida y de qué manera vigilar y modular el financiamiento y gasto sectoriales? sobre todo cuando estos están conformados mayormente por recursos privados e individuales. En la búsqueda de las respuestas, no puede pasarse por alto la tensión entre la autonomía y la interdependencia de los bienes privados y públicos y sus implicaciones para la solidaridad y la equidad.

En materia de aseguramiento, el Estado tiene la responsabilidad de tutelar una efectiva protección social en materia de salud garantizando el acceso a un plan básico de cobertura de servicios de salud para todos los habitantes. Ello exige que se desarrolle la capacidad institucional de los ministerios o secretarías de salud para definir el contenido de los planes básicos de cobertura universal. También es preciso desarrollar mecanismos para la vigilancia del aseguramiento garantizado que haya sido definido y para comprar o prestar servicios subsidiarios, a fin de cumplir con los planes de cobertura garantizados (15).

En este contexto, el ámbito de las responsabilidades gubernamentales y los mecanismos vinculantes para que el Estado actúe como garante de la protección social en materia de salud deben ser cuidadosamente definidos. Para ello es preciso responder a preguntas como ¿en qué medida y cómo normar y vigilar el aseguramiento?, sobre todo cuando éste es mayormente el resultado de una prestación social ligada al empleo o de una relación contractual o voluntaria de individuos y grupos con empresas de carácter privado o solidarista, es decir, sin fines de lucro. Las tensiones entre el derecho laboral y la solidaridad, así como entre la autodeterminación y libertad de asociación y negociación y la corres- ponsabilidad social por el cuidado de la salud, tienen que ser tomadas en cuenta a la hora de normar y vigilar el acceso de todos a un plan básico de seguro de salud.

La tendencia a reducir la intervención gubernamental en la provisión de servicios de salud mediante diferentes mecanismos, con el fin de proporcionar a múltiples actores sociales (privados, públicos autónomos y organizaciones solidarias no gubernamentales) la oportunidad de participar en dicha provisión, condiciona el ámbito y la práctica de la coordinación estatal de proveedores entre los cuales raras veces hay una relación jerárquica.

Bajo las reformas de salud de los años noventa, la organización del sector de la salud mostró una tendencia contraria a la de décadas anteriores. Ya no se buscaba unificar todas las acciones, programas e instituciones en un esquema de centralización administrativa, operativa e incluso institucional, sino que los nuevos modelos se caracterizaban por la búsqueda de la especialización institucional y la descentralización. Las nuevas tendencias en la gestión pública señalaban, además, la conveniencia de que las dependencias y entidades públicas, con el fin de mejorar su eficacia, eficiencia y transparencia, separaran sus competencias, asignándolas a diversas organizaciones. Esto tenía por objeto desagregar las funciones de dirección con respecto a las del control; las funciones de regulación con respecto a las del aseguramiento; las funciones de financiación con respecto a las de provisión (1). Como resultado, los ministerios o secretarías de salud tendieron a desligarse cada vez más de la gestión directa de la provisión de servicios para concentrase en la función rectora de dirigir y coordinar la provisión de servicios ejercida por otros actores.

Al rediseñar la organización de los sistemas de atención de salud, se deberá evaluar la asignación de cada función, teniendo en cuenta en cada caso cuáles pueden ser privatizadas y cuáles delegadas a las entidades subnacionales. 
La privatización y la descentralización suponen necesariamente una pérdida del control administrativo por el nivel central del gobierno y el otorgamiento de libertades discrecionales a los niveles subnacionales y entidades no estatales en la ejecución de las competencias delegadas. Ello ha exigido que la descentralización se acompañe de mejoras en la armonización estatal y en el control social que permitan sustituir el control administrativo central por nuevos contenidos y formas en que se orienta y coordina la provisión pluralista local. A fin de desarrollar la capacidad de los entes rectores para armonizar la provisión descentralizada, es necesario previamente responder a preguntas como cuánto $\mathrm{y}$ cómo se dirige y articula la provisión pluralista de los servicios de atención a la salud frente a actores que tienen personería jurídica independiente $\mathrm{y}$ autonomía financiera y funcional.

\section{CONCLUSIONES}

Todos estos interrogantes, además de otros que están relacionados con la nueva dimensión del ejercicio de la autoridad sanitaria en el Estado moderno, no demeritan en modo alguno la trascendencia y magnitud de la responsabilidad gubernamental inalienable de ejercer la rectoría de la salud como política pública y bien social. Más bien resaltan la trascendencia y magnitud de la responsabilidad rectora de la autoridad sanitaria y evidencian la complejidad de su práctica.

Resulta evidente que el nuevo perfil de la función rectora, resultado de los procesos de modernización estatal y manifiesto en la reforma del sector de la salud, se diferencia cualitativamente, en magnitud y complejidad, de la práctica previa de la rectoría sectorial. Asimismo, la nueva dimensión de la rectoría sectorial exige una capacidad institucional y personal que no coincide con la organización, marco legal, liderazgo político, capacidades técnicas e instrumental operacional vigentes en la mayoría de los ministerios o secretarías de salud. De ahí que la reconversión de dichos ministerios o secretarías y el fortalecimiento de su capacidad para la rectoría sectorial no puedan abordarse mediante acciones aisladas de capacitación, ingeniería organizacional y desarrollo instrumental, teniendo que planificarse y ejecutarse con un enfoque integrado de desarrollo institucional (16).

Como consecuencia de todo lo antedicho, los diferentes países se han planteado el fortalecimiento de la capacidad de rectoría de los entes que ejercen la autoridad sanitaria en los Estados como un quehacer prioritario en el marco de los procesos de reforma del sector de la salud.

\section{REFERENCIAS}

1. Jaramillo I. Macrocondicionamientos externos al proceso de fortalecimiento de la rectoría de los ministerios de salud. Washington, D.C.: Organización Panamericana de la Salud, División de Desarrollo de Sistemas y Servicios de Salud; 1998. (Serie Organización y Gestión de Sistemas y Servicios de Salud No. 5).

2. World Bank. World development report 1997: the State in a changing world. Washington, D.C.: World Bank; 1998.

3. Blair T. La Tercera Vía: una democracia social moderna. The Guardian, 7 de febrero de 1998.

4. The World Bank Group. Health, nutrition, and population sector strategies. Washington, D.C.: World Bank; 1997.

5. Programa de las Naciones Unidas para el Desarrollo, Banco Interamericano de Desarrollo. Reforma social y pobreza: hacia una agenda integrada de desarrollo. Nueva York: PNUD, BID; 1993.

6. Banco Mundial. El fomento del desarrollo social: contribución del Banco Mundial a la Cumbre Social. Washington, D.C.: BM; 1995.

7. World Health Organization. Health in social development: position paper of the World Health Organization (WHO) in the World Summit for Social Development. Geneva: WHO; 1995.
8. Naciones Unidas. Hacia un nuevo paradigma de la acción estatal en el ámbito social: pautas para un plan de acción para el fortalecimiento de la administración pública y la gestión de las políticaas sociales. Nueva York: Naciones Unidas, Departamento de Apoyo al Desarrollo y de Servicios de Gestión; 1995.

9. Kliksberg B. Repensando el Estado para el de sarrollo social: más allá de dogmas y convencionalismos. Nueva York: Naciones Unidas, División de Gobernabilidad, Administración Pública y Finanzas; 1997.

10. Rodríguez-García R, Goldman A. The health development link. Washington, D.C.: George Washington University and Pan American Health Organization; 1994.

11. Cunill N. Repensando lo público a través de la sociedad: nuevas formas de gestión pública y representación social. Caracas: Centro Latinoamericano de Administración para el Desarrollo; 1997.

12. Macedo C Guerra de. Desarrollo de la capacidad de conducción sectorial en salud: una propuesta operacional. Washington, D.C.: Organización Panamericana de la Salud, División de Desarrollo de Sistemas y Servicios de Salud; 1998. (Serie Organización y Gestión de Sistemas y Servicios de Salud No. 6).
13. Cañón L. El nuevo papel de las regulaciones gubernamentales en salud a cargo de los ministerios de salud. Washington, D.C.: Organización Panamericana de la Salud, División de Desarrollo de Sistemas y Servicios de Salud; 1998. (Serie Organización y Gestión de Sistemas y Servicios de Salud No. 7).

14. Organización Panamericana de la Salud. Funciones esenciales de salud pública: una perspectiva desde las prácticas sociales. Washington, D.C.: OPS, División de Desarrollo de Sistemas y Servicios de Salud; 1998.

15. Hurtado M. La cuestión del aseguramiento y el nuevo paradigma de los ministerios de salud en el contexto de la reforma. Washington, D.C.: Organización Panamericana de la Salud, División de Desarrollo de Sistemas y Servicios de Salud; 1998. (Serie Organización y Gestión de Sistemas y Servicios de Salud No. 8).

16. Marín JM. La institucionalización de la capacidad de rectoría sectorial de salud en el Estado moderno. Ponencia presentada en el Panel sobre el Ejercicio de la Rectoría de la Salud por la Autoridad Sanitaria en el Estado Moderno, III Congreso Internacional de CLAD, Madrid, España, octubre de 1998. 
ABSTRACT Strengthening the ability of health authorities to provide leadership and guidance, now and in the future, is an important issue within the context of health sector reform.

\section{Strengthening the steering} role of health authorities within the context of health sector reform
It means, among other things, redefining the role of health in light of leading social and economic trends seen in the world at the beginning of the 21st century, increasing participation in health by nongovernmental entities, moving toward participatory democracy in many countries, and modifying concepts of what is considered "public" and "private." Within this scenario, it is necessary to redirect the role of the health sector toward coordinating the mobilization of national resources, on a multisectoral scale, in order to improve equity and social well-being and to channel the limited available resources to the most disadvantaged groups in society.

The liberalization of the production and distribution of health-related goods and services, including insurance, challenges the exercise of authority in the area of health. Furthermore, the formation of regional economic blocks and the enormous weight wielded by multinational companies in the areas of pharmaceuticals and other medical supplies and technologies are forcing the health sector to seek ways of harmonizing health legislation and international negotiations. According to many experts, all of these demands surpass the ability of Latin American ministries of health to effectively respond, given most countries' current organizational, legal, and political conditions and technical infrastructure. The countries of the Americas must make it a priority to strengthen their health officials' ability to provide leadership and guidance in order to meet present and future challenges. 